\title{
SUMMARY OF THE LAND-USE INVENTC RY FOR THE NONPOINT-SOURCE EVALUATION MONITORING WATERSHEDS IN WISCONSIN
}

By J.A. Wierl, K.F. Rappold, and F.U. Amerson

U.S. GEOLOGICAL SURVEY

Open-File Report 96-123

Prepared in cooperation with the

WISCONSIN DEPARTMENT OF NATURAL RESOURCES

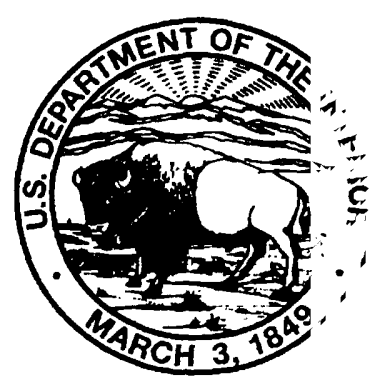

Madison, Wisconsin

1996 


\title{
U.S. DEPARTMENT OF THE INTERIOR BRUCE BABBITT, Secretary
}

\author{
U.S. GEOLOGICAL SURVEY \\ Gordon P. Eaton, Director
}

For additional information write to:

Copies of this report can be purchased from:

District Chief

U.S. Geological Survey

6417 Normandy Lane

Madison, WI 53719
U.S. Geological Survey

Earth Science Information Center

Open-File Reports Section

Box 25286, MS 517

Denver Federal Center

Denver, CO 80225 


\section{CONTENTS}

Abstract.

Introduction

Land-use inventory methods

Quantification of nonpoint-source pollutants...

Animal waste.

Streambank erosion

Upland erosion

Manure spreading.

Gully erosion.

Tracking of land use and implementation of best-management practices

Database development and maintenance

Outputs and queries.

Land-use inventory results

Quantification of nonpoint-source pollutants

Animal-waste management.

Streambank protection

Upland best-management practices

Tracking of land use and implementation of best-management practices

Difficulties with database development and maintenance

Implementation of best-management practices.

Monitoring activities planned for water year 1996

References cited.

Appendix: Elements of the Wisconsin nonpoint source water pollution abatement program

\section{FIGURES}

1-7. Maps showing:

1. Locations of nonpoint-source evaluation monitoring watersheds and reference watersheds in Wisconsin.

2. Eligible, contracted, and implemented best-management practices, Brewery Creek Watershed, Wisconsin

3. Eligible, contracted, and implemented best-management practices, Garfoot Creek Watershed, Wisconsin

4. Eligible, contracted, and implemented best-management practices, Joos Valley and Eagle Creek Watershed, Wisconsin

5. Eligible, contracted, and implemented best-management practices, Bower Creek Watershed, Wisconsin.

6. Eligible, contracted, and implemented best-management practices, Otter Creek Watershed, Wisconsin

7. Contracted and implemented best-management practices, Rattlesnake and

Kuenster Creek Watershed, Wisconsin.

\section{TABLES}

1. Features of the nonpoint-source evaluation monitoring watersheds, Wisconsin

2. Features of the reference watersheds for the nonpoint-source evaluation monitoring watersheds, Wisconsin

3. Selection, assessment, approval, sign-up, and funding dates for evaluation monitoring watersheds, Wisconsin

4. Summary of eligible, contracted, and implemented rural best-management practices in nonpoint source evaluation monitoring watersheds, Wisconsin.

5. Nonpoint sources of pollutants in nonpoint-source evaluation monitoring watersheds, Wisconsin.

6. Pollutant reduction goals for nonpoint-source evaluation monitoring watersheds, Wisconsin 


\section{CONVERSION FACTORS}

Multiply

acre

foot (ft) mile (mi) square mile $\left(\mathrm{mi}^{2}\right)$ pound (lb)

ton per year

ton per acre per year ton per mile per year
By

0.4048

0.3048

1.609

2.590

453.6

0.9072

2.242

0.5638
To Obtain

hectare

meter

kilometer

square kilometer

gram

megagram or metric ton per year megagram per hectare per year megagram/kilometer/year

Temperature in degrees Fahrenheit $\left({ }^{\circ} \mathrm{F}\right)$ can be converted to degrees Celsius $\left({ }^{\circ} \mathrm{C}\right)$ by use of the following equation:

${ }^{\circ} \mathrm{C}=5 / 9\left({ }^{\circ} \mathrm{F}-32\right)$. 


\title{
SUMMARY OF THE LAND-USE INVENTORY FOR THE NONPOINT-SOURCE EVALUATION MONITORING WATERSHEDS IN WISCONSIN
}

\author{
By J.A. Wierl, K.F. Rappold, and F.U. Amerson
}

\section{Abstract}

In 1992, the Wisconsin Department of Natural Resources (WDNR) in cooperation with the U.S. Geological Survey initiated a land-use inventory to identify sources of pollutants and track the land-management changes for eight evaluation monitoring watersheds established as part of the WDNR's Nonpoint Source Program. Each evaluation monitoring watershed is within a WDNR priority watershed. The U.S. Geological Survey is responsible for collection of water-quality data in the evaluation monitoring watersheds. An initial inventory was completed for each of the WDNR priority watersheds before nonpoint-source plans were developed for the control of nonpoint pollution. The land-use inventory described in this report expands upon the initial inventory by including nonpoint pollution sources that were not identified and also by updating changes in landuse and land-management practices. New sources of nonpoint pollution, not identified in the initial inventory, could prove to be important when monitored and modeled data are analyzed. This effort to inventory the evaluation monitoring watersheds will help with the interpretation of future land-use and water-quality data. This report describes landuse inventory methods, presents results of the inventory, and lists proposed future activities.

\section{INTRODUCTION}

Since the late 1970's, the Wisconsin Nonpoint Source (NPS) Program (Appendix) has provided financial assistance to local governments for the implementation of best-management practices (BMP's). Implementation of BMP's, with technical assistance from local Land Conservation Departments (LCD's), is aimed at reducing nonpoint-source pollction of Wisconsin streams.

By the mid-1980's, it was clear that very little data existed to prove the effectiveness of using BMP's in Wisconsin's priority watersheds ${ }^{1}$. In response to this need for data, the Wisconsin Departmen ${ }^{+}$of Natural Resources (WDNR) began a comprehensive, multidisciplinary evaluation monitoring program in 1990 to assess the effectiveness of the Wisconsin NPS program. This evaluation monitoring progra $m$ includes biological and stream-habitat monitoring by the WDNR and water-quality monitoring by the U.S. Geological Survey (USGS). All evaluation monitoring program watersheds are within priority watersheds; these watersheds were selected to represent the major stream types and priority watersheds targeted by' the NPS Program.

The installation of BMP's is a very slow process, and the effects of these practices on water resources may require at least a decade of monitoring to evaluate. The monitoring is divided into three stages: "preBMP" conditions, transitional, and "post-BMP" conditions (Graczyk and others, 1993). The monitoring period will allow the researchers the time necessary to isolate changes in water quality resulting from natural variability and those resulting from BMP implementation. Ultimately, results from the evaluation monitoring program will be used to assess the effect veness of the types and number of BMP's recommended by the Wisconsin NPS Program.

The original evaluation study design provided for a comprehensive analysis of biological, physical, and chemical attributes; however, a need still existed for collecting data on land-use changes and the progress in the use of BMP's within the monitored

${ }^{1}$ The Wisconsin Nonpoint Source Program focuses on critical hydrologic units called "priority watersheds." 


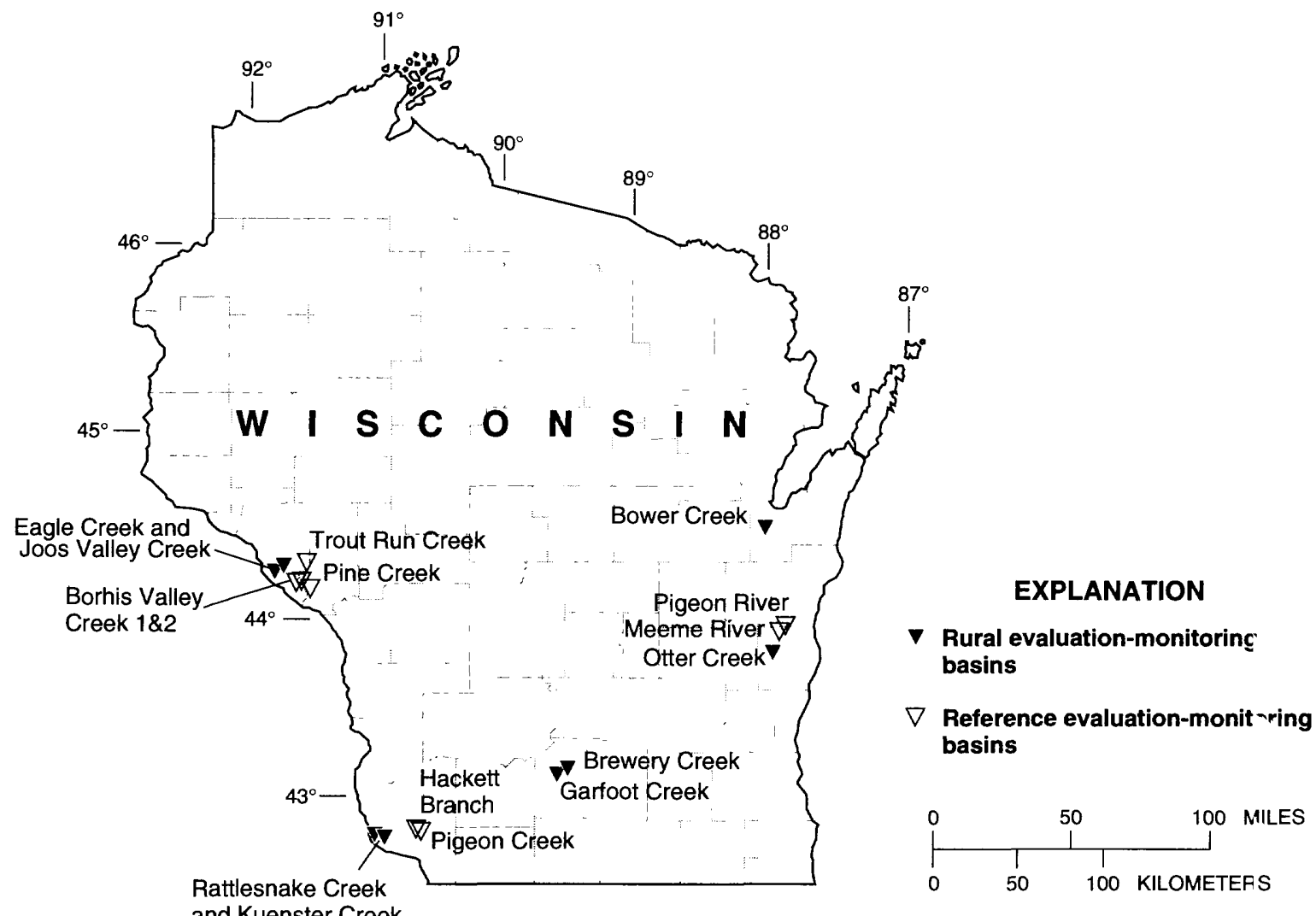

Figure 1. Locations of nonpoint-source evaluation monitoring watersheds and reference watersheds in Wisconsin

watersheds. Information on the critical sources of nonpoint pollution and how these sources change with the implementation of BMP's is important to the interpretation of evaluation monitoring results. Hence, a landuse inventory was initiated in 1992 to provide this necessary information on nonpoint pollution sources and BMP implementation.

This report summarizes rural land-use data and describes data collection methods for the nonpointsource evaluation monitoring program. Specifically, the report contains rural land-use data on the eight watersheds that were chosen for study. The watersheds differ in their topography, soil types, natural vegetation, and land uses. The watersheds selected als? differ considerably in stream gradient and fisheries classification (table 1). In addition, seven rural watersheds were chosen to function as references for the monitored watersheds (fig. 1). Land characteristics of these reference watersheds are similar to those in the moritored watersheds, but BMP's will not be implemente-1 because the watersheds arenot in a priority watershed. The seven reference watersheds will be used tc help discern the changes in stream-water quality that result 

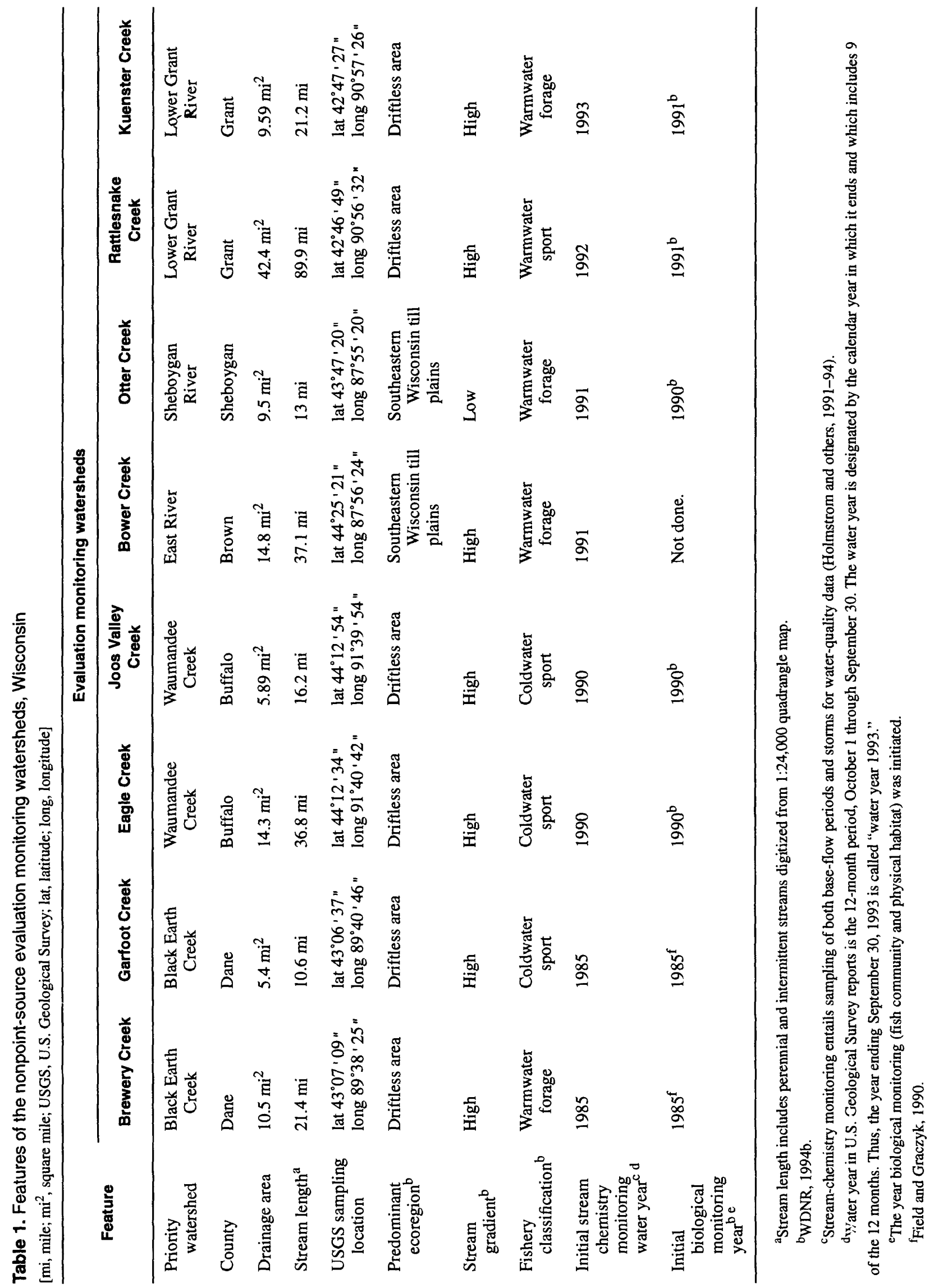
from BMP implementation in the monitored watersheds (table 2).

The first part of the report is a description of the land-use inventory methods. The second part gives the results obtained through the land-use inventory. In the third part, proposed future activities of the land-use inventory team ${ }^{2}$ are listed.

\section{LAND-USE INVENTORY METHODS}

Nonpoint pollution sources, land use, and BMP's are quantified by the land-use inventory team with an array of sources and methods. The primary data sources include nonpoint-source control plans, field inventories, conservation plans for farm operations, county databases, and other agricultural management agencies. Methods for quantifying nonpoint pollution sources and changes in land use, and tracking for BMP's have been developed by the NPS Program, local LCD's, other agricultural management agencies, and the land-use inventory team. Nonpoint-source control plans for the priority watersheds in which the evaluation monitoring watersheds are located are the single largest source of data. Other necessary data are obtained primarily through the land-use inventory.

Initially, watershed descriptions were developed for each of the evaluation monitoring watersheds to establish a baseline for future data analysis. The watershed descriptions include information on location, climate, soil types, topography, nonpoint pollution sources, and surface-water resources. This information was compiled primarily from the nonpoint-source control plans, county soil surveys, conservation plans, and data generated from other evaluation monitoring efforts. A comparison of baseline data in the watershed descriptions with data collected in the future is expected to be an important component of the land-use inventory.

The land-use inventory team primarily identifies and quantifies agricultural sources of pollutants, which include barnyard-animal waste, streambank erosion, upland soil loss, and manure spreading. Additional nonpoint-source pollutants, such as construction-site runoff and soil from ephemeral and permanent gullies, are also quantified. Information on quantity of nonAmerson. point-source pollution and progress in the use of BMP's has been obtained for all the evaluation monitoring watersheds.

Working relationships have been established with the local LCD's to facilitate the acquisition of current data for the evaluation monitoring watersheds. Working relationships have also been maintained with agencies that administer other programs that affect water quality, such as the Natural Resources Conservation Service (NRCS), Department of Agriculture Trade and Consumer Protection (DATCP), and the Farm Service Agency (FSA). Land-management changes brought about by these other programs may be as significant as those attributed to the NPS Program. In addition, data collected by these agencies on farm characteristics, sources of pollutants, or management practices form a significant part of the land-use inventory.

The collection of information on farm operations, pollutant sources, and use of BMP's will be achieved most effectively through a collaborat:ve effort. Attempts are being made to avoid duplic'tion in current and future data collection. Consequently, the working relationships developed between the USGS and WDNR with local LCD's and other agencie` are an important facet of the land-use inventory.

\section{Quantification of Nonpoint-Source Pollıtants}

Nonpoint-source control plans were developed by the WDNR for the priority watersheds in which the evaluation monitoring watersheds are located (table 3 ). These plans include a priority watershed assessment and a detailed procedure for implementation. The priority watershed assessment documents the pric rity watershed characteristics, water-quality conditions and objectives, nonpoint sources, and management actions. Detailed procedure for BMP implementation lists the roles and responsibilities for the project particioants, BMP's which are cost-shared by the NPS Program, and the information and education program (Wisconsin Department of Natural Resources, 1989, 1990, 1991, 1993a, 1993b).

The NPS Program requires land-management actions, which are carried out through the use of BMP's, to control sources of nonpoint pollution in priority watersheds. To achieve these managemert. actions, program managers have established eligibility 


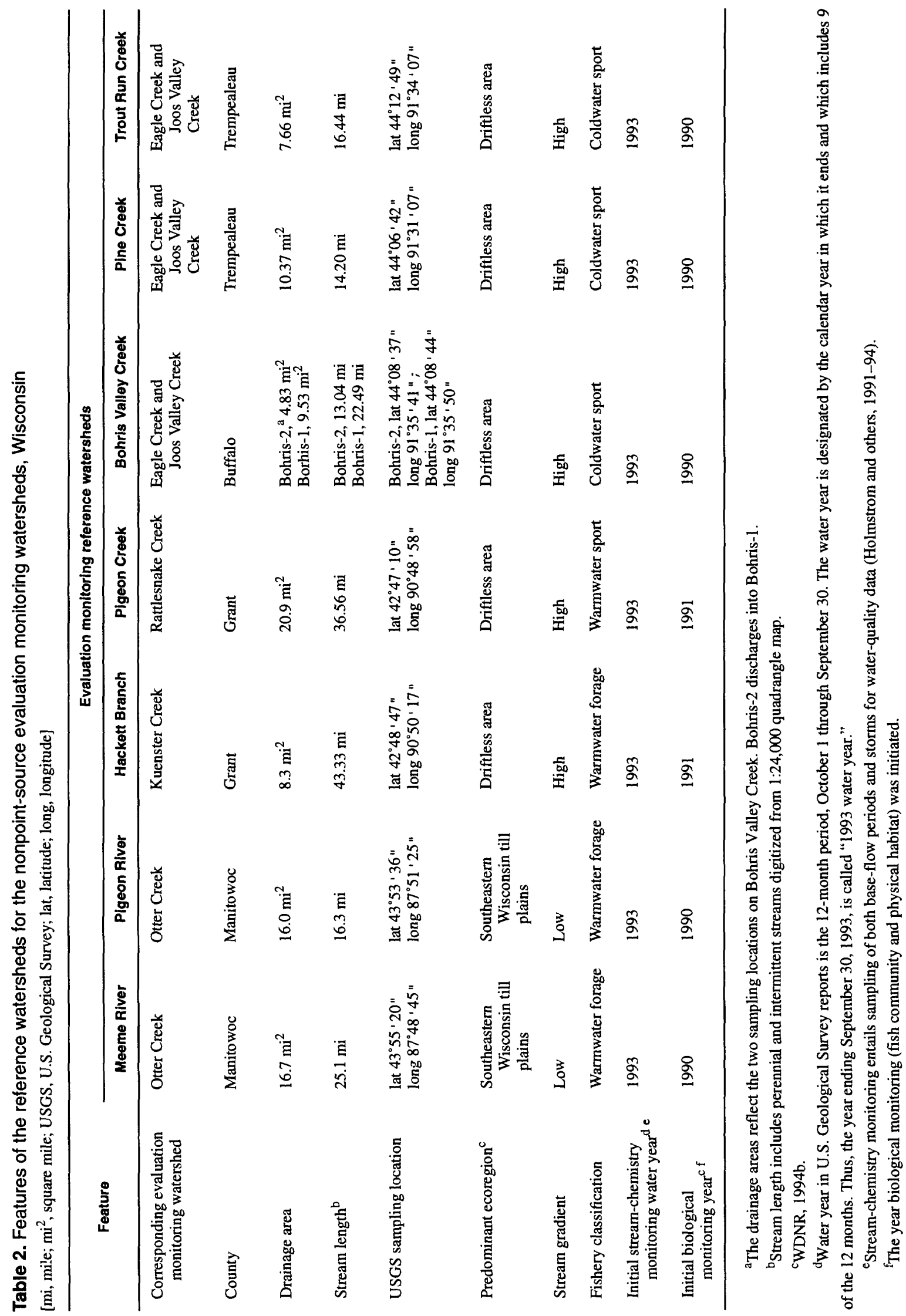


Table 3. Selection, assessment, approval, sign-up, and funding dates for evaluation monitoring watersheds, Wisconsin

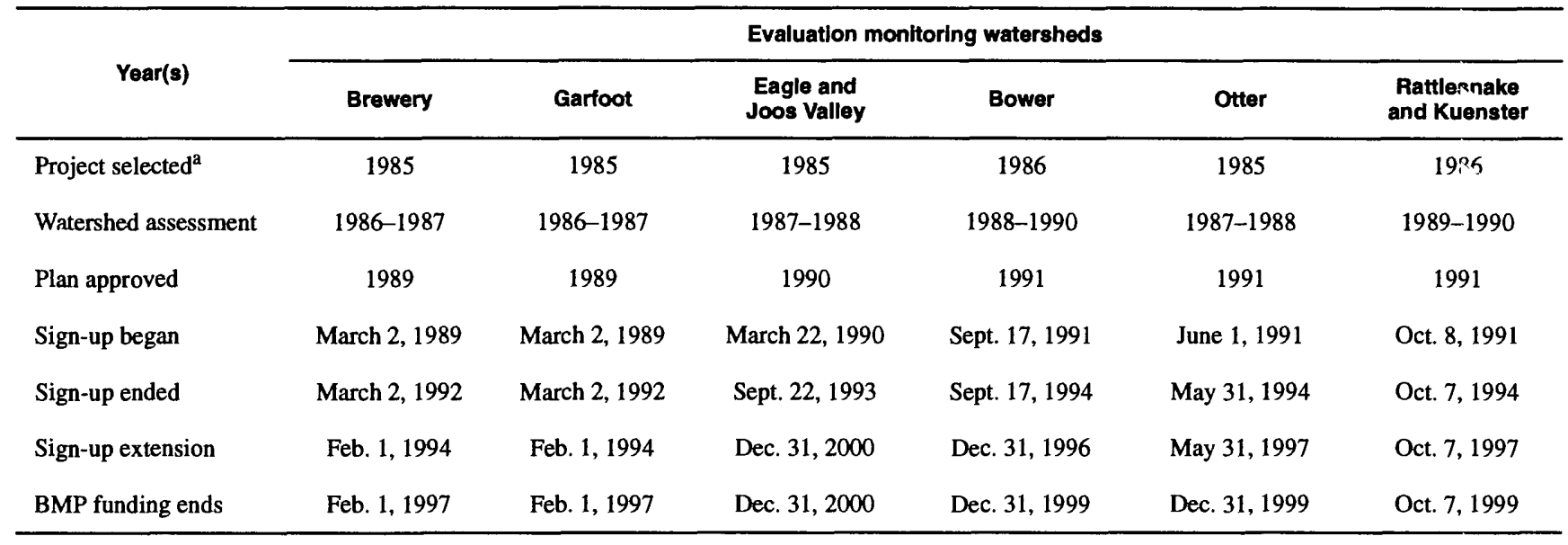

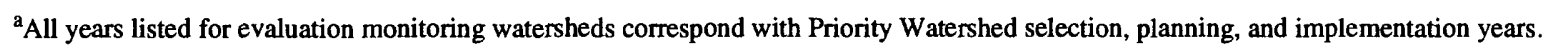

criteria and management categories in nonpoint-source control plans. Eligibility criteria determine which local land operators will receive funding according to the severity of nonpoint-source pollution. Management categories define the priorities for addressing nonpoint sources of pollutants. Management categories are defined in the appendix.

Eligibility criteria for BMP funding and management categories are established for animal waste, streambank erosion, upland erosion, manure spreading, and other nonpoint sources of pollutants. These critical sources of nonpoint pollutants were selected through extensive priority watershed inventories. Priority watershed inventories are done by local LCD's with funding support from the WDNR.

Data not found in the nonpoint-source control plans, or inventory data that have become outdated, are augmented or updated by the land-use inventory team. This is accomplished through field inventories on pollutant sources and by running various pollutant-loading models. Identifying and quantifying these pollution sources may prove important for the interpretation of monitoring results and the selection of future BMP's. The nonpoint-source quantification methodology of the NPS Program and the land-use inventory team is described in the following sections.

\section{Animal Waste}

All the barnyards in the evaluation monitoring watersheds were inventoried by the local LCD's (Wisconsin Department of Natural Resources, 1989, 1990, 1991, 1993a, 1993b). Data collected include the size of the yard, the types and numbers of livestock, ard the physical characteristics of the areas contributing surface runoff to the yard and receiving surface runoff from the yard. Estimates of barnyard-runoff pollutant quantities are generated from the BARNY model, which is a modification of the animal-lot runoff model developed by the U.S. Department of Agriculture (USDA), Agricultural Research Service (Wisconsin Department of Natural Resources, 1994c). Pollutantloading estimates generated for the priority-watershed barnyards are ranked according to the specific eligibility criteria and management actions needed.

\section{Streambank Erosion}

Typically, only the main channels of the streams in the evaluation monitoring watersheds were inventoried for erosion potential by the local LCD's (W'isconsin Department of Natural Resources, 1989, 1990, 1991, 1993a, 1993b). The technique used to evaluate streambank erosion is a modification of the streambank-erosion assessment used in the Land Inventory Monitoring (LIM) Program by the USDA, Natural 
Resources Conservation Service. For each streambankerosion site, the LIM method is used to estimate the volume and mass of sediment lost on a yearly average. This is accomplished through measuring the length, height, and recessional rate of each erosion site. Eroded streambank sites are targeted for BMP's according to the eligibility criteria and management actions listed in the nonpoint-source control plans.

Streambank-erosion inventories were done by the land-use inventory team in almost all the evaluation monitoring watersheds in 1994. All perennial streams in an inventoried evaluation monitoring watershed were surveyed. The modified LIM method for streambank erosion was used for the inventory. New pollutant loadings for eroded streambanks computed by the landuse inventory team are being compared against the data from the nonpoint-source control plans.

\section{Upland Erosion}

All the upland fields in the evaluation monitoring watersheds were inventoried by the local LCD's (Wisconsin Department of Natural Resources, 1989, 1990, 1991, 1993a, 1993b). Existing data and field investigations were used by the local LCD's to identify and quantify upland sheet and rill erosion. The existing data include site-specific conservation plans developed by the NRCS, aerial photographs, USGS quadrangle maps, and county soil surveys. The Wisconsin Nonpoint Source (WIN) model was used for estimating sediment delivery from upland erosion. WIN is an empirical water-quality model that calculates the average quantity of eroded soil reaching surface waters from each farm field (Wisconsin Department of Natural Resources, 1994a). This model uses factors such as parcel size, soil type, slope percent and length, land cover, present management, overland-flow distance and destination, channel type, and receiving water.

A land-use database is being developed by the land-use inventory team to facilitate the running of sediment-delivery models. Data needed to run these models is obtained from the local county databases, NRCS conservation plans, USGS quadrangle maps, WIN data, and county soil surveys. These data include hydrologic-unit delineations, soil type, slope percent and length, land cover, present management, overlandflow characteristics, channel type, and receiving water. Models are used to recalculate upland erosion and sed- iment delivery, which are compared with the data from the nonpoint-source control plans.

\section{Manure Spreading}

Critical areas for manure spreading were identified by the local LCD's using results from the upland and barnyard inventories (Wisconsin Department of Natural Resources, 1989, 1990, 1991, 1993a, 1993b). A three-step process was used to assess critical areas for manure spreading. In the first step, investigators estimated how much land each livestock operation needed to spread manure over the 180-day-frozenground period. Second, this amount of land was compared to the acreage suitable for winter spreading for each landowner according to the upland sedimentdelivery inventory data. Finally, an estimate was made of the acres of unsuitable land, on an average basis, that were used for manure disposal during $\mathrm{t} 1 \cdot 180$-day period.

\section{Gully Erosion}

In 1995, a gully-erosion inventor' was done by the land-use inventory team to identify and quantify these sources of pollution in all the evalıation monitoring watersheds. The gully-erosion inventory method is a modification of the erosion method in luded in the LIM program. The method uses data on the length of eroded gully, the vertical depth, the average width, and the length of time it took for the gully tc develop. This method gives the total tons of eroded sc il per year. In only one of the evaluation monitoring watersheds was an inventory of gully erosion completed for its nonpoint-source control plan.

\section{Tracking of Land Use and Implem sntation of Best-Management Practices}

\section{Database Development and Maintencnce}

A database is being developed to track and manage changes in data describing land use. watershed characteristics, and implementation of PMP's. It is an interactive system that links geographical data with tabular data by use of a geographic information system 
(GIS), ARC/INFO software ${ }^{3}$. This database will then be used to run models and to produce geographical maps.

The database was developed using the following steps:

1. Establish a base map for each evaluation monitoring watershed by digitizing USGS 7.5minute quadrangles. The base map includes watershed outline, hydrographic characteristics, major roads, and the location of USGS stream-chemistry monitoring stations and rain gages.

2. Local LCD's identify and locate all eligible, contracted, and implemented BMP's which is digitized into a GIS spatial data layer.

3. Establish a land-use spatial data layer and enter the corresponding field attributes into a database. This database would include soil type from county soil surveys, land use from field inventories, and nonpoint pollution sources from initial inventories data.

Activities to update the geographical and tabular database are the following:

1. Annual updates of land-use and BMP changes that occur within the watershed.

2. Digitize the hydrologic units for each of the evaluation monitoring watersheds.

3. Generate slope and aspect information from digital elevation models using the GIS.

4. Convert data into a tabular form to be used for modeling. Data generated by use of the GIS include watershed boundaries, hydrologic units, and elevations. Other data tables would include variables such as soil factors, land cover, streamflow characteristics, and rainfall (event and annual) data.

\section{Outputs and Queries}

Outputs that will be generated from the database are the following:

\section{Annual maps showing changes in animal} waste, streambank and upland BMP's.

\footnotetext{
${ }^{3}$ The use of ARC/INFO and other trade names is for identification purposes only and does not constitute endorsement by the U.S. Geological Survey.
}

2. Annual maps showing land-use changes, such as crop rotation.

3. A map of results from model runs depirting sediment and phosphorus loading from individual fields.

Queries that could be done with the database are the following:

1. What are the pollutant loadings for a critical area (sediment yield, phosphorous load`, average soil loss, sediment deposition, and so forth)?

2. How many fields are highly erodible? Are these fields being treated, and if so, by what practice?

3. Where is gully erosion found? What type of gully erosion is taking place? What is the sediment delivery to stream?

4. What is the status of a particular BMP practice?

5. Is the land under another Federal program, and when did the local government begin participating?

\section{LAND-USE INVENTORY RESULTS}

The land-use inventory team has compilet data on the evaluation monitoring watersheds. The results of the inventory are summarized in the section entitled, "Quantification of Nonpoint Source Pollutants." This section includes animal-waste management, streambank protection, and upland BMP's. For each evaluation monitoring watershed, BMP implementatic $\rightarrow$ and land use changes are being tracked. This informetion is depicted on maps that are annually updated. Some of the difficulties in developing and maintaining the database are discussed.

To understand the effects of land-use char res or BMP implementation on streamwater quality, investigators collected descriptive information on each of the evaluation monitoring watersheds. The watersheds are found in two distinct ecoregions: the Driftless Area and the southeastern Wisconsin till plains. The drainage areas of the evaluation monitoring watersheds range from approximately $5 \mathrm{mi}^{2}$ to more than $40 \mathrm{mi}^{2}$. These watersheds are tributary to the Mississippi and V'isconsin Rivers and also to Lake Michigan. 


\section{Quantification of Nonpoint-Source Pollutants}

\section{Animal-Waste Management}

The construction and use of an animal-waste management practice helps improve water quality. Table 4 lists a summary of eligible, contracted, and implemented rural best-management practices for each of the evaluation monitoring watersheds. To control phosphorus loadings, animal-waste management practices are implemented (table 4). Nonpoint sources of pollutants in each of the evaluation monitoring watersheds are listed in table 5. The phosphorus load in table 5 reflects contributions from barnyards and may include additional phosphorus loading at locations where eligible manure storage facilities are not implemented. Phosphorus loads from critical acres of winter spread-manure are not listed in table 5 because it is difficult to quantify. A significant reduction ( $70-85$ percent control goal) in phosphorus loading in the evaluation monitoring watersheds may require a high implementation level of barnyard-control systems (table 6). In the nonpoint-source inventory, the local LCD's used BARNY, a modified version of the NRCS ARS model, to quantify barnyard eligibility on the basis of phosphorus loadings. In each watershed, all the barnyards were inventoried by either one person or a team to achieve a consistent estimate, which provided a correlation between pollutant loadings from each barnyard during a 10-year, 24-hour storm event. Therefore, the land-use team is in agreement with the barnyard assessment and those barnyards chosen for animal-waste management practices. BARNY can be rerun if a dramatic change occurs at a particular barnyard, such as change in the size of a herd, or if a practice is implemented. BMP's for controlling barnyard pollutants include diversions to direct surface runoff around the barnyard, settling basin, filter walls, and vegetated filter strips (Wisconsin Department of Natural Resources, 1989, 1990).

\section{Streambank Protection}

Restricting cattle access and stabilizing eroded streambanks improves the riparian habitat and reduces sedimentation and nutrient delivery to surface water. Improvements from a specific streambank-protection practice are difficult to detect because several practices may be used to control an eroding site. The land-use inventory team surveys all perennial streambanks to calculate a current sediment loading. $\mathrm{Tl} \cdot$ relatively small drainage areas of the evaluation monitoring watersheds facilitate an extensive streambank inventory by the land-use inventory team. In contrast, the estimation of streambank sediment loac'ings for the nonpoint source inventories were more difficult because the inventories covered a much larger area. The practices contracted and implemented to correct the streambank erosion based on the original inventory are listed in table 4. Results of streambank inventories by the local LCD's and the land-use inventory team are listed in table 5. The primary BMP's fo* streambank protection include stabilizing shorelines. shaping and seeding streambanks, restricting livesto $\mathrm{k}$ access (fencing), and rehabilitating fish habitat. If most BMP's are implemented, the streambank sedimant reduction might achieve the goals listed on table $\epsilon$.

\section{Upland Best-Management Practices}

In the nonpoint-source control plans, the goal of a 30- to 75-percent reduction in sediment entering surface-water bodies was recommended (table 6). Most of this reduction will be achieved by implementation of BMP's to prevent and control upland sheet and rill erosion. The local LCD's develop a nutrient-management plan at the request of a rural land operator or if an upland and (or) manure-storage facility BMP is contracted (table 4). Most nutrient-management plans recommended fertilizer- and manure-application rates, not pesticide-application rates.

To determine upland erosion and sediment delivery to surface water from a farm field, the local LCD's use the WIN model. The results from th local LCD's are listed in table 5. The WIN model requires a random 20 -percent inventory to complete model runs. However, the evaluation monitoring watersheds are usually less than 15 percent of the entire priority watershed, and they may have not been inventoried originally; therefore, the land-use inventory team p' ans to run several models to determine the upland erocion and sediment deliveries to the monitored stream ${ }^{-}$. Uplanderosion BMP's include changes in crop rotations, change to permanent cover, minimum reduced tillage, contour and strip cropping, and grassed waterways (Wisconsin Department of Natural Rescrurces, 1989). 


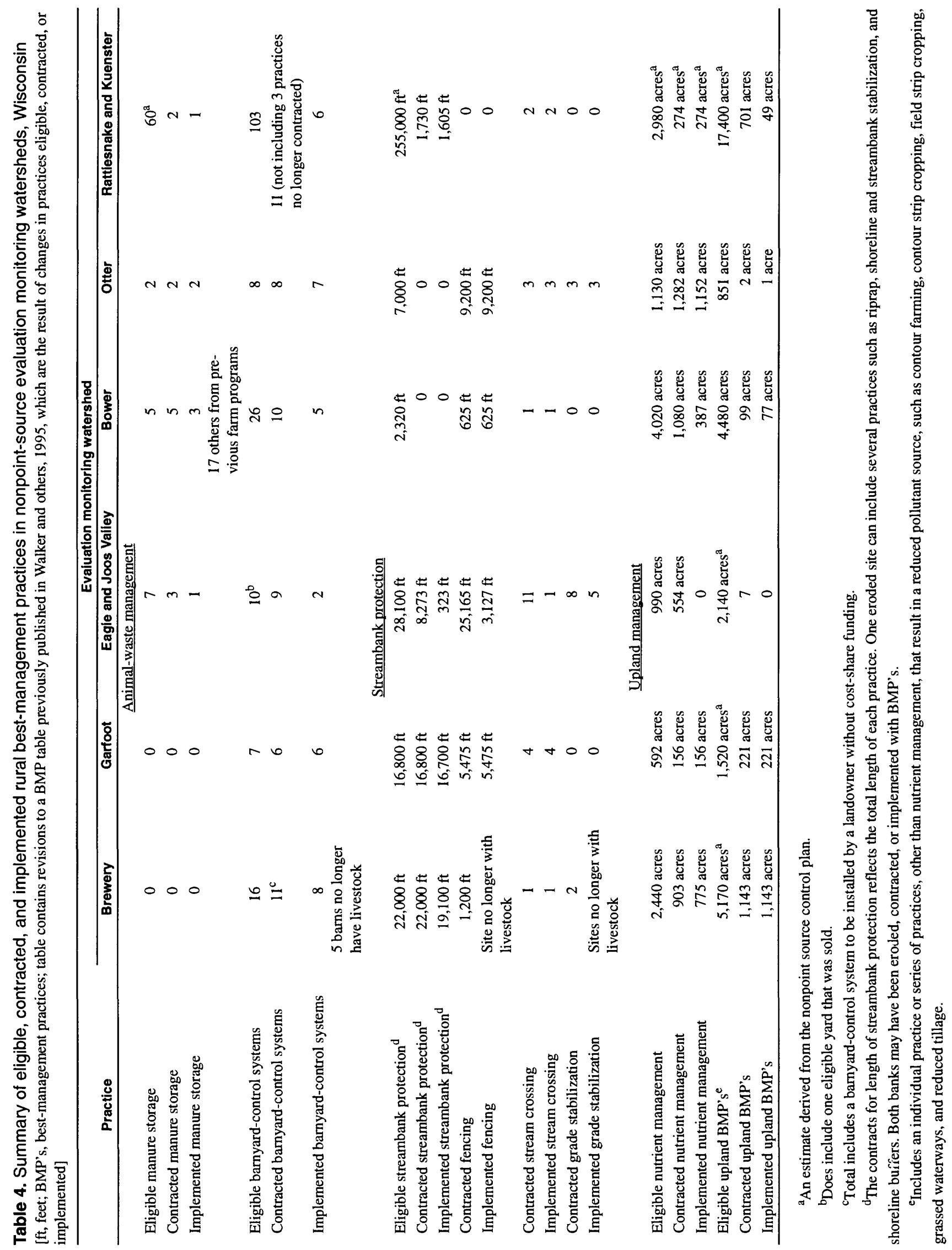


Table 5. Nonpoint sources of pollutants in nonpoint-source evaluation monitoring watersheds, Wisconsin [lb, pounds; ton/acre/yr, tons per acre per year; ton/mi/yr, tons per stream mile per year; \%, percent; N/A, information not available]

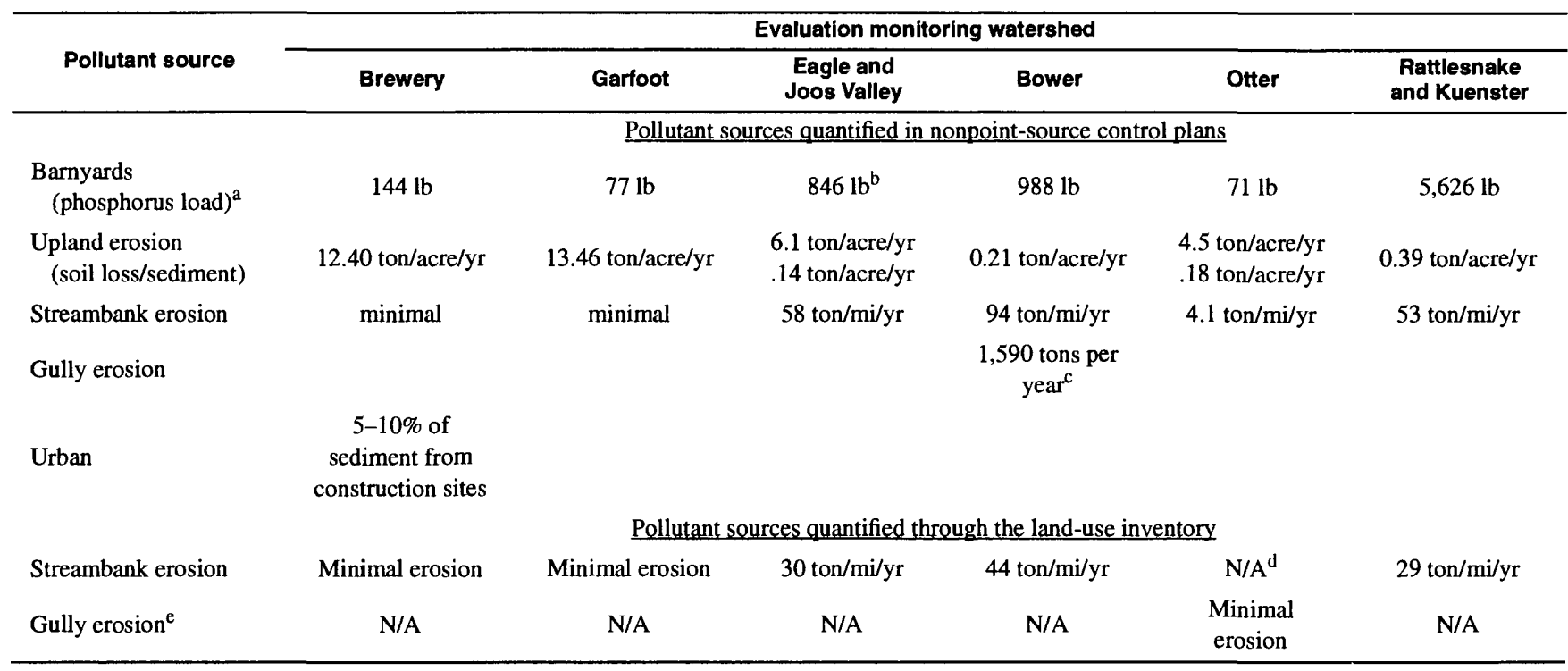

${ }^{a}$ Based on the modified Agricultural Research Service Barnyard Runoff Model (10-year, 24-hour storm event).

bTotal phosphorus load for entire Priority Watershed subwatershed.

${ }^{\mathrm{c}}$ Gully erosion for entire Priority Watershed subwatershed.

${ }^{\mathrm{d}}$ Watershed not inventoried in 1995, will be completed in 1996.

${ }^{\mathrm{e}}$ Gully erosion inventory will be completed in 1996.

Table 6. Pollutant reduction goals for nonpoint-source evaluation monitoring watersheds, Wisconsin

[Evaluation monitoring watersheds may be divided into subwatersheds (such as upper and lower Bower for the Bower Creek evaluation monitoring watershed); \%, percent]

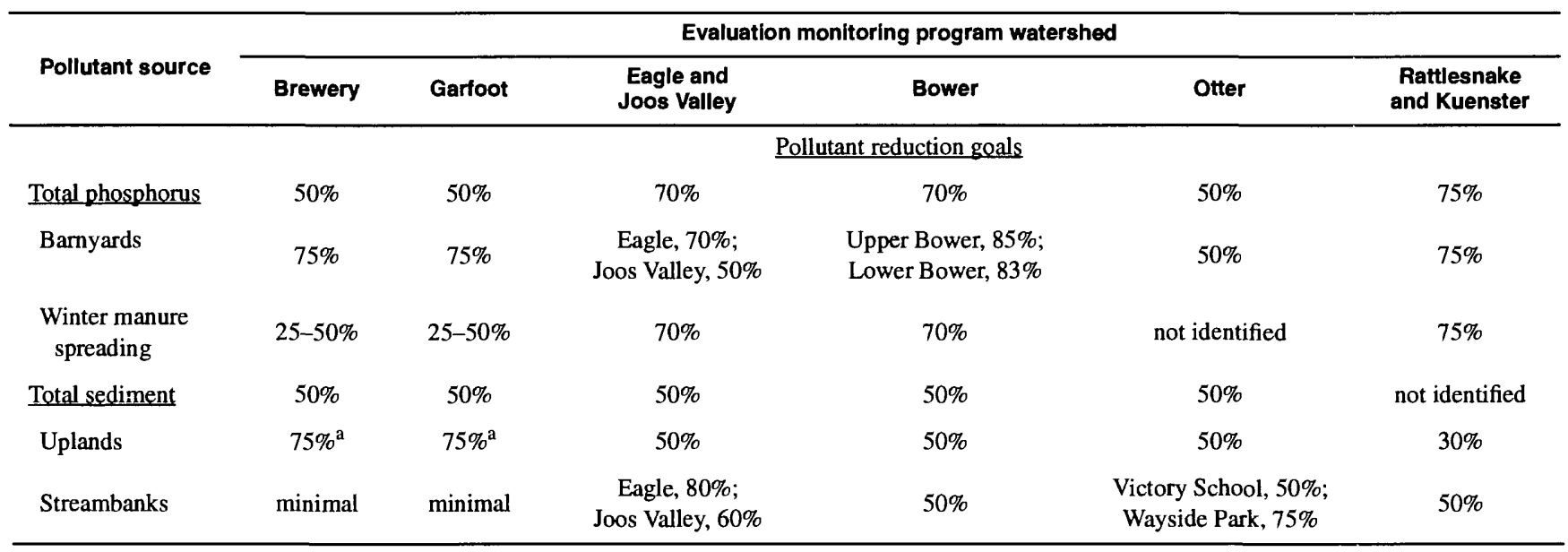

${ }^{\text {a }}$ The soil erosion reduction needed to achieve the sediment reduction goal. 


\section{Tracking of Land Use and Implementation of Best-Management Practices}

\section{Difficulties with Database Development and Maintenance}

Establishing a uniform land-use spatial data layer for each of the evaluation monitoring watersheds has been difficult. Among the difficulties are the following:

1. Delineations of the Otter Creek, Bower Creek, and Rattlesnake Creek Watersheds boundaries in the nonpoint-source control plans are different than those for the evaluation monitoring watersheds. This discrepancy causes difficulties in obtaining compatible data from local LCD's and the NRCS.

2. The NRCS is in the process of converting all data from the Computer Assisted Management and Planning System (CAMPS) database to the Field Office Computing System (FOCS) database for improved maintenance of data. It is uncertain how long the conversion will take for all the evaluation monitoring watersheds. For those counties that use the FOCS system, a downloading program was written to convert FOCS tables into a format that can be uploaded into the land-use inventory database. For those counties without FOCS, the land-use inventory team is in the process of inputting the original inventory data by scanning or typing the information into the land-use database.

3. Obtaining a geographical representation of the modeled data is difficult. For each model to be run, several data conversions are needed and substantial checking of data is required in between each transfer.

4. A lack of compatible data between NRCS, local LCD's, and FSA offices hindered data collection; problems included lack of consistency in field numbering and boundary delineation.

5. In several counties, nonrectified FSA air photos were used instead of orthophotos to delineate field boundaries. Use of nonrectified photos also could introduce error in modeling.

\section{Implementation of Best-Management Practicns}

NPS Program goals for improving surface-water quality rely heavily on a high percentage of BMP implementation. Currently, the rate of contracting or implementation of BMP's at eligible sites is less than 100 percent in all the evaluation monitoring watersheds. Therefore, the question remains whether any of the water-resource objectives or pollutant-reduction goals will be achieved in the evaluation monitoring watersheds.

The selection, assessment, approval, sign-up, and funding dates for the evaluation monitoring watersheds are listed in table 3 . Each of the nonpoint-s ource control plans has designated a span of time for contracting of BMP's. All the evaluation monitoring watersheds have been granted an extension by the NPS Program. The extensions allow the local LCD's time to achieve a greater reduction of pollution by contrs ting more BMP's, but the extensions lengthen the amo'nt of time the evaluation monitoring program must continue.

The evaluation monitoring watershed closest to achieving its BMP implementation goal is Otter Creek. In that watershed, 100 percent of its eligible animalwaste systems are contracted, and a high percentage of some of the other needed BMP's also are contracted (table 4). In the Rattlesnake Creek Watershed, by contrast, less than 10 percent of the eligible animal-waste management systems have been contracted. How'ever, observations from the field inventories of the evaluation monitoring team showed that a lack of streambank protection in Rattlesnake Creek Watershed could be a greater problem than slow implementation of barnyard-management systems.

In the other evaluation monitoring watersheds, contracted and implemented levels of BMP's are somewhere between those in the Otter Creek and Rattlesnake Creek Watersheds. Critical sites that are eligible for BMP's and whether they are contracted or implemented are located in table 4. Animal-waste-management practices or streambank practices for each of the evaluation monitoring watersheds are located on figures 2-7. 


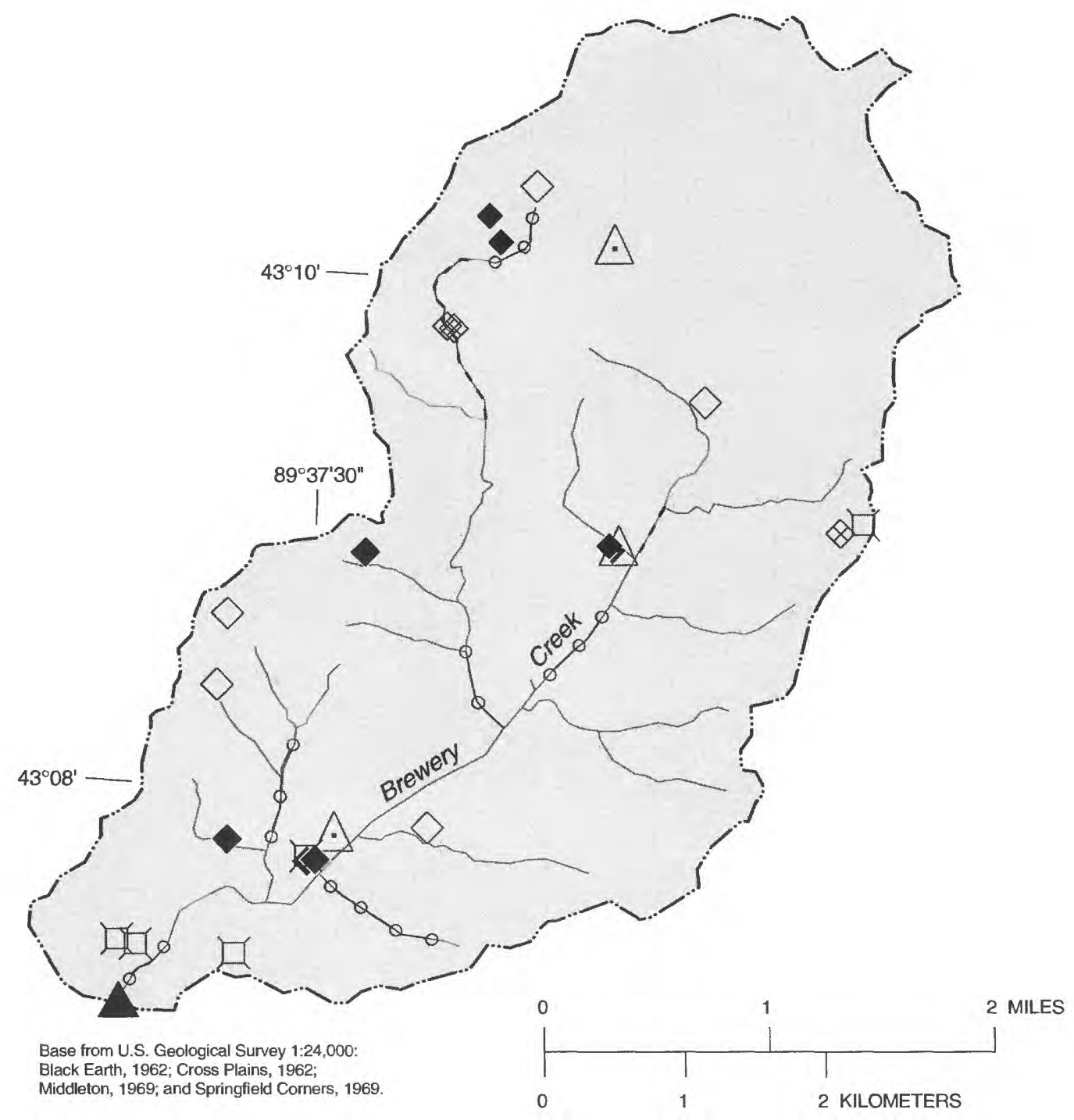

EXPLANATION

... Basin boundary

__ _ Eligible streambank protection

- Implemented streambank protection

Stream gage

A Rain gage
Contracted manure storage

Eligible barnyard control system

Contracted barnyard control system (includes one system not cost-shared)

Implemented barnyard control system

Barnyard no longer has livestock

Figure 2. Eligible, contracted, and implemented best-management practices, Brewery Creek Watershed, Wisconsin. 


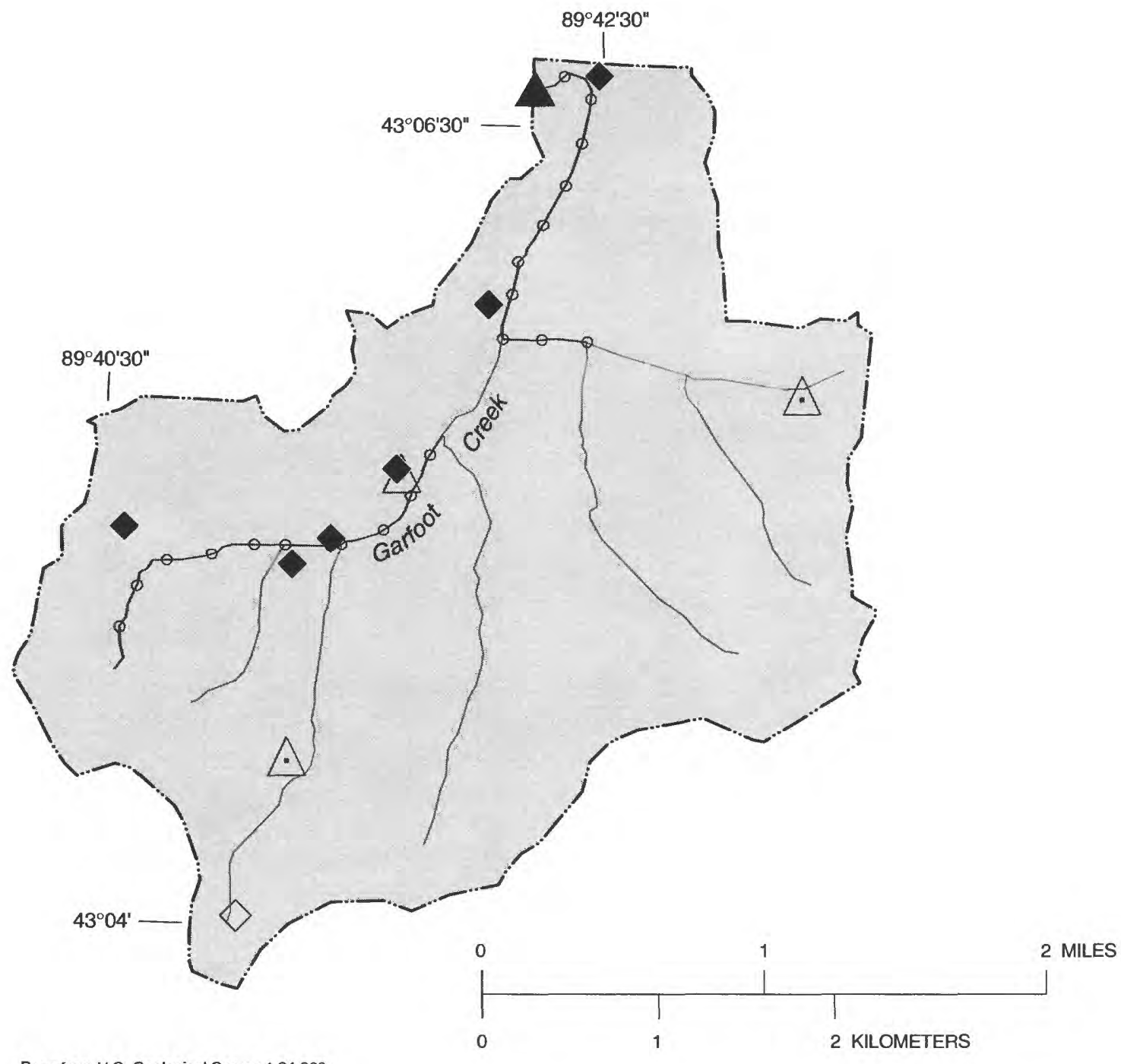

Base from U.S. Geological Survey 1:24,000: Cross Plains, 1962.

\begin{tabular}{|l|l|}
\hline & E X P L A N A T I O N \\
\hline \multirow{2}{*}{ B Basin boundary } & Rain gage \\
\hline Stream gage & Eligible barnyard control system \\
\hline
\end{tabular}

Figure 3. Eligible, contracted, and implemented best-management practices, Garfoot Creek Watershed, Wisconsin. 


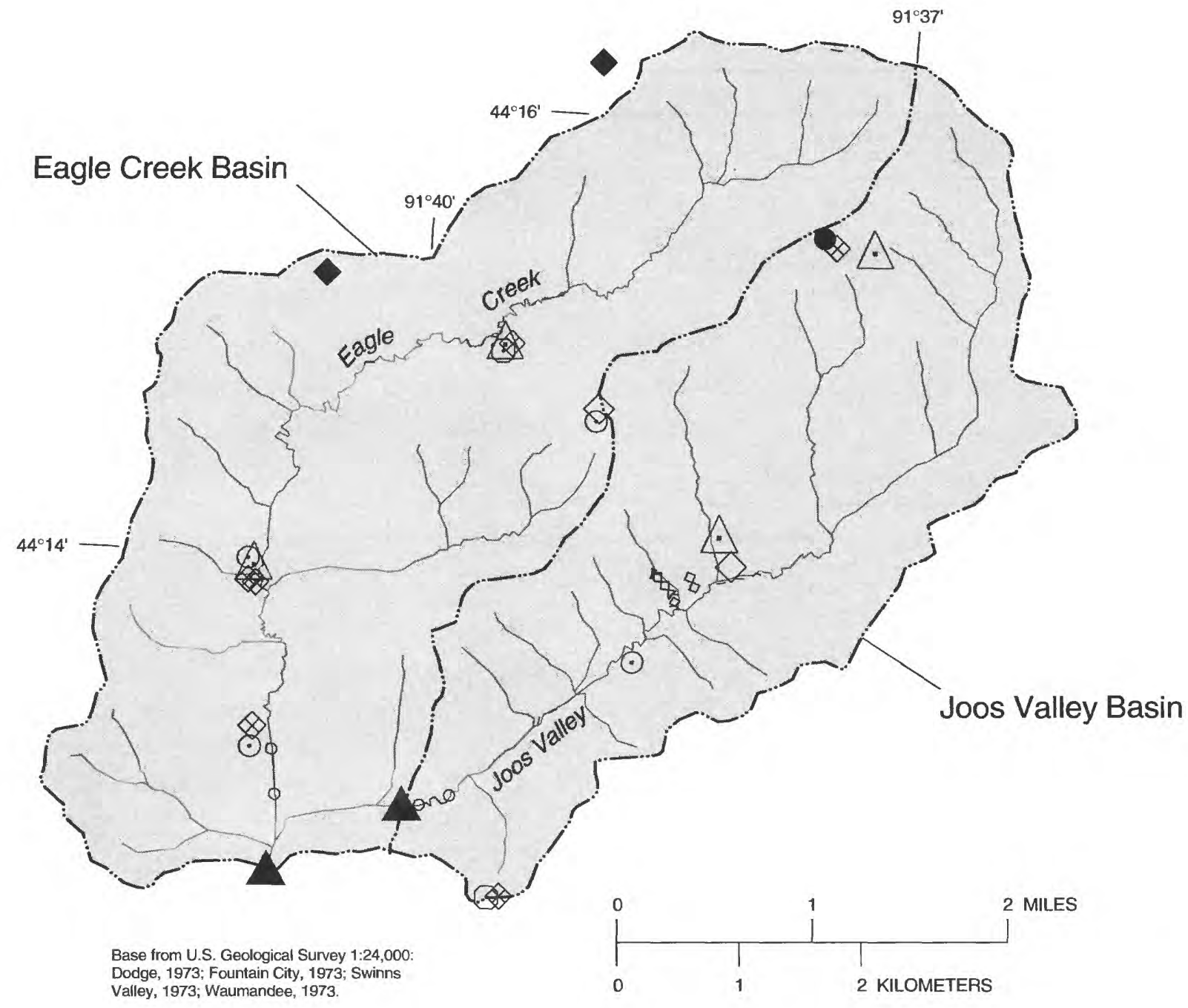

Dodge, 1973; Fountain City, 1973; Swinns

Valley, 1973; Waumandee, 1973

\begin{tabular}{|c|c|c|c|}
\hline \multicolumn{4}{|c|}{ EXPLANATION } \\
\hline & Basin boundary & $\odot$ & Eligible manure storage \\
\hline$\infty \infty \infty$ & Contracted grassed waterway & $\odot$ & Contracted manure storage \\
\hline & Contracted streambank protection & ? & Implemented manure storage \\
\hline$\theta$ & Implemented streambank protection & $>$ & Eligible barnyard control system \\
\hline & Stream gage & $\otimes$ & Contracted barnyard control system \\
\hline$\triangle$ & Rain gage & 4 & Implemented barnyard control system \\
\hline
\end{tabular}

Figure 4. Eligible, contracted, and implemented best-management practices, Joos Valley and Eagle Creek Watershed, Wisconsin. 


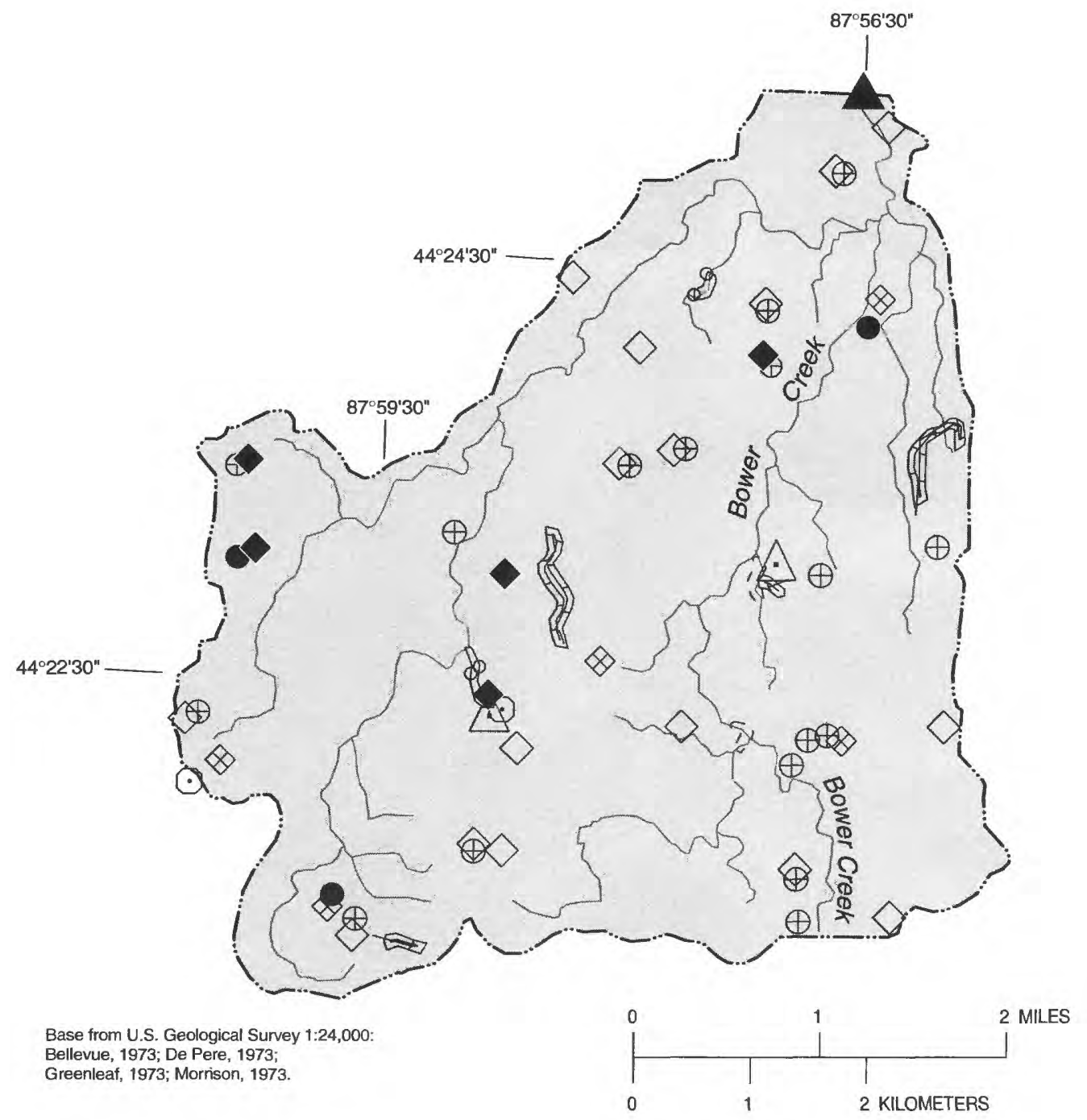

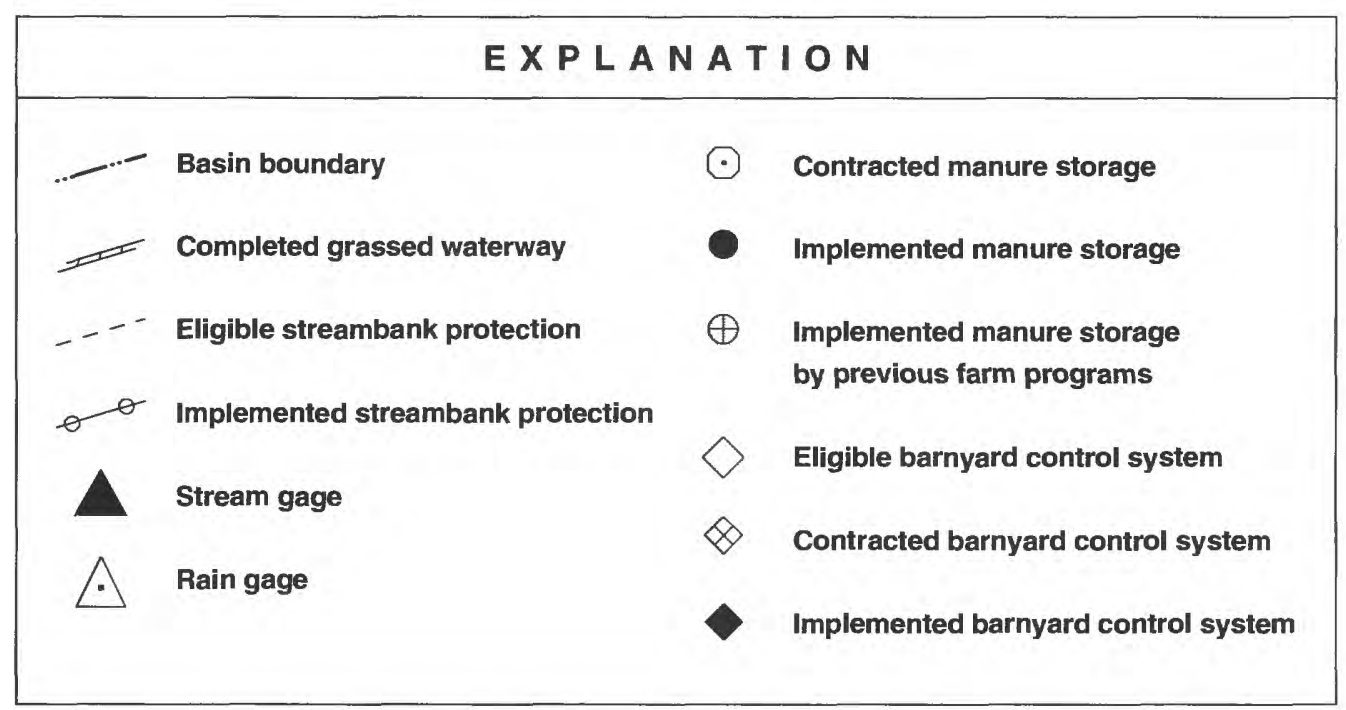

Figure 5. Eligible, contracted, and implemented best-management practices, Bower Creek Watershed, Wisconsin. 


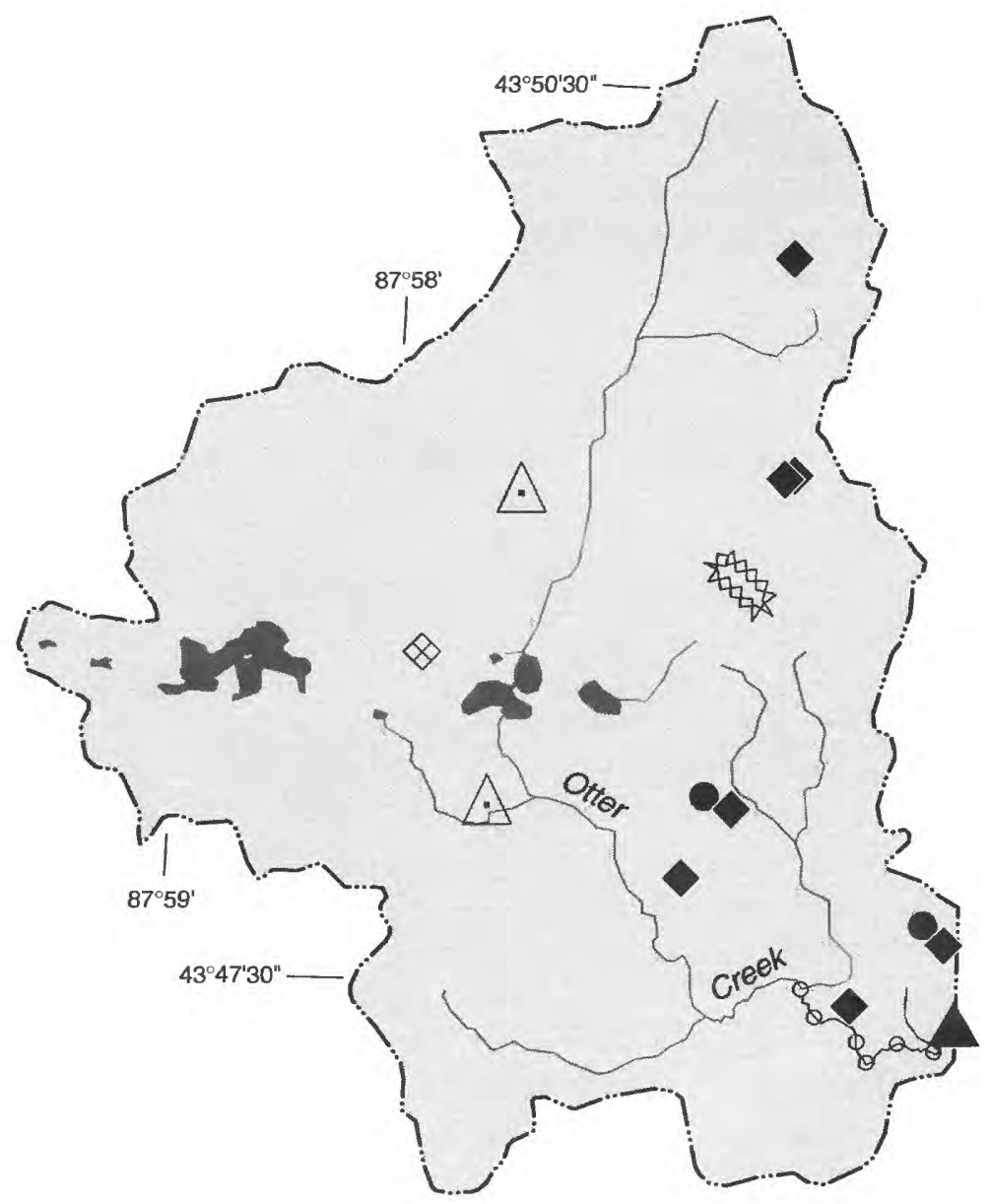

Base from U.S. Geological Survey 1:24,000: Franklin, 1973.

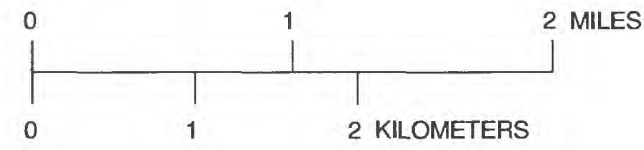

EXPLANATION

B. Basin boundary
Stream gage

Figure 6. Eligible, contracted, and implemented best-management practices, Otter Creek Watershed, Wisconsin. 


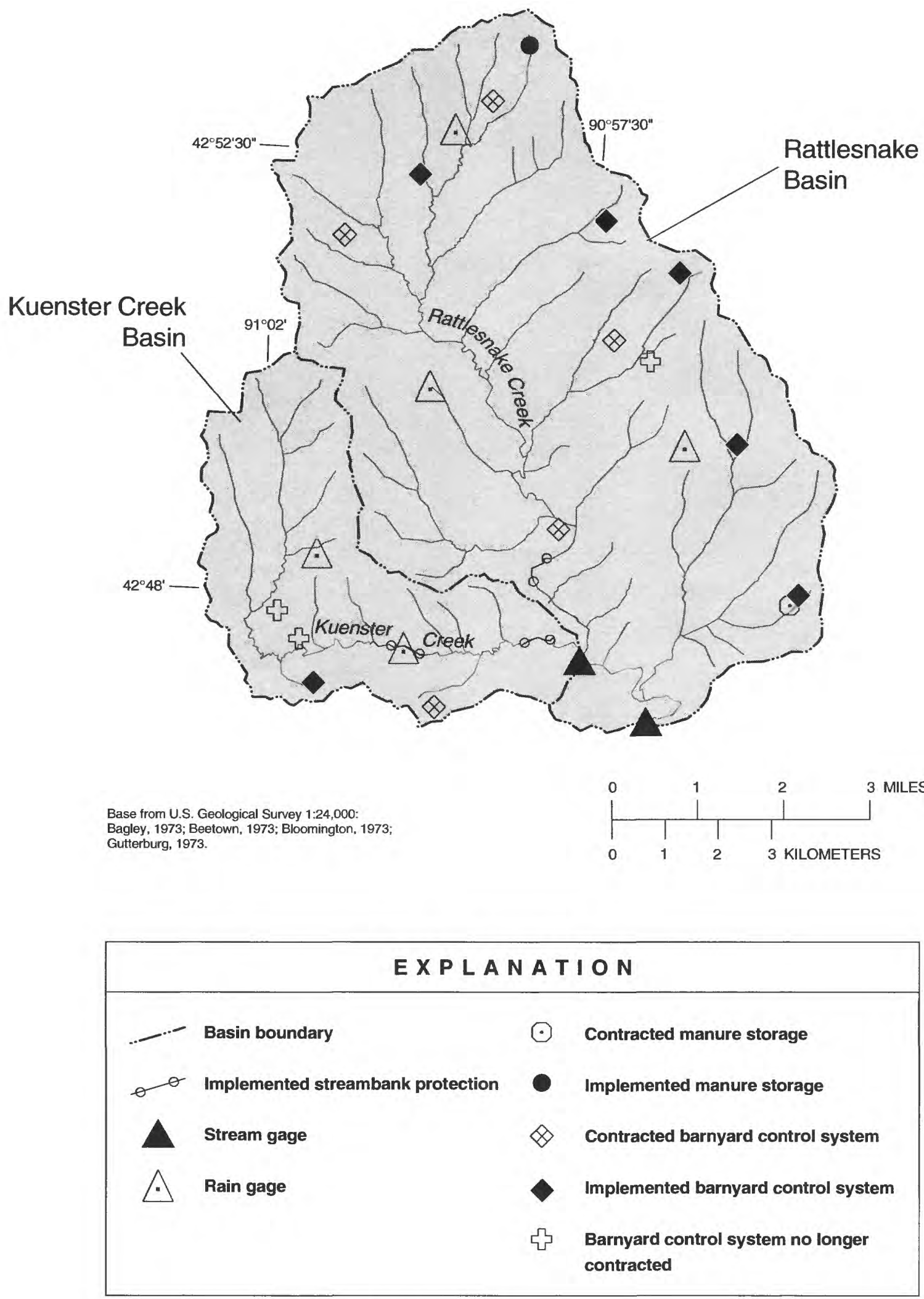

*Eligible practices not shown in this figure (see Table 4).

Figure 7. Contracted and implemented best-management practices, Rattlesnake and Kuenster Creek Watershed, Wisconsin. 


\section{MONITORING ACTIVITIES PLANNED FOR WATER YEAR 1996}

The following land-use and BMP-monitoring activities are planned for water year 1996:

1. Update the GIS database that contains all pertinent land-use data. The database will contain the information necessary to create land-use maps and to generate sediment and phosphorus loads from land-use-management models.

2. Publish a collection of evaluation monitoring watershed descriptions, incorporating the original priority-watershed inventories and progress of each local LCD in implementing BMP's.

3. Produce a manual on updating and maintaining the land-use inventory database.

4. Complete an inventory of crop rotations and gully erosion in each watershed.

5. Obtain nutrient-management plans for farm operations with livestock.

\section{REFERENCES CITED}

Corsi, S.R., Walker, J.F., Graczyk, D.J., Greb, S.R., Owens, D.W., and Rappold, K.F., 1995, Evaluation of nonpointsource contamination, Wisconsin-selected streamwaterquality data, land-use and best-management practices inventory, and quality assurance and quality control, water year 1993: U.S. Geological Survey Open-File Report 94707, $57 \mathrm{p}$

Engel, R.J., Roberts, B.A., and Steingraeber, J.A., 1978, Soil survey of Sheboygan County, Wisconsin: U.S. Department of Agriculture, Soil Conservation Service [variously paged].

Field, S.J., and Graczyk, D.J., 1990, Hydrology, aquatic macrophytes, and water quality of Black Earth Creek and its tributaries, Dane County, Wisconsin, 1985-86: U.S.

Geological Survey Water-Resources Investigations Report $89-4089,38 \mathrm{p}$.

Glocker, C.L., and Patzer, R.A., 1978, Soil survey of Dane County, Wisconsin: U.S. Department of Agriculture, Soil Conservation Service [variously paged].

Graczyk, D.J., Walker, J.F., Greb, S.R., Corsi, S.R., and Owens, D.W., 1993, Evaluation of nonpoint-source contamination, Wisconsin - selected data for 1992 water year: U.S. Geological Survey Open-File Report 93-630, 48 p.

Holmstrom, B.K., and others, 1991-94, Water resources data, Wisconsin, water years 1990-93: U.S. Geological Survey Water Data Reports WI 90-1 through WI 93-1 and WI 912 through WI 93-2 (published annually).
Konrad, J.G., Baumann, J.S., and Bergquist, S.E., 1985, Nonpoint pollution control- the Wisconsin experience: Journal of Soil and Water Conservation, v. 40, no. 1, p. 55-61.

Link, E.G., and others, 1974, Soil survey of Brown County, Wisconsin: U.S. Department of Agriculture, Soil Conservation Service [variously paged].

Robinson, G.H., and Klingelhoets, A.J., 1961, Soil survey of Grant County, Wisconsin: U.S. Department of Agriculture, Soil Conservation Service [variously paged].

Thomas, D.D., Carroll, P.H., and Wing, G.N., 1962, Soil Survey of Buffalo County, Wisconsin: U.S. Department of Agriculture, Soil Conservation Service [variously paged].

U.S. Department of Commerce, 1993, Climatological data, Wisconsin-annual summary with comparative data: National Oceanic and Atmospheric Administration, $6 \mathrm{p}$.

Walker, J.F., Graczyk, D.J., Corsi, S.R., Owens, D.W., and Wierl, J.A., 1995, Evaluation of nonpoint-source contamination, Wisconsin-land-use and best-management practices inventory, selected streamwater-quality data, urbanwatershed quality assurance, and quality control, constituent loads in rural streams, and snowmelt-runoff analysis, water year 1994: U.S. Geological Survey Open-File Report 95-320, 21 p.

Wisconsin Department of Agriculture, Trade and Consumer Protection, 1994, Wisconsin agricultural statistics-1994, $98 \mathrm{p}$.

Wisconsin Department of Natural Resources, 1989, A plan for the control of nonpoint sources and related resource management in the Black Earth Creek priority watershed, report WR-218-89 [variously paged].

Wisconsin Department of Natural Resources, 1990, A nonpoint source control plan for the Waumandee Creek priority watershed project, report WR-274-90, $150 \mathrm{p}$.

Wisconsin Department of Natural Resources, 1991, A plan for the control of nonpoint sources and related resource management in the Lower Grant River priority watershed, report WR-293-91 [variously paged].

Wisconsin Department of Natural Resources, 1993a, A nonpoint source control plan for the East River priority watershed project, report WR-274-93, $188 \mathrm{p}$.

Wisconsin Department of Natural Resources, 1993b, A nonpoint source control plan for the Sheboygan River watershed, report WR-265-93, $227 \mathrm{p}$.

Wisconsin Department of Natural Resources, 1994a, WINHUSLE-model documentation and user's manual, version 1.4.4, report WR-294-91 [variously paged].

Wisconsin Department of Natural Resources, 1994b, Evaluation of the Wisconsin priority watershed program for improving stream habitat and fish communities: Wisconsin Department of Natural Resources Progress Report (1993), $115 \mathrm{p}$.

Wisconsin Department of Natural Resources, 1994c, BARNY 2.2-The Wisconsin barnyard runoff model, inventory instructions and user's manual, report WR-285-91, 35 p. 
APPENDIX 


\section{ELEMENTS OF THE WISCONSIN NONPOINT SOURCE WATER POLLUTION ABATEMENT PROGRAM}

The following information on the Wisconsin Nonpoint Source Water Pollution Abatement Program is summarized from Konrad and others, (1985) and Wisconsin Department of Natural Resources (1989, 1990, 1991, 1993a, 1993b).

The Wisconsin Nonpoint Source Water Pollution Abatement Program (the NPS program) was created in 1978 by the State Legislature. The program's goal is to improve and protect the water quality of streams, lakes, wetlands, and ground water by reducing pollutants from urban and rural nonpoint sources. Nonpoint sources include eroding agricultural lands, eroding streambanks, animal lots, fields spread with manure, eroding construction sites, streets, and parking lots. Pollutants from nonpoint sources are carried to the surface water or ground water through the action of rainfall runoff, snowmelt, and seepage.

The program is administered by the Wisconsin Department of Natural Resources (WDNR) and the Wisconsin Department of Agriculture, Trade and Consumer Protection (DATCP). Program administration, technical expertise in water-quality assessment and cost-share and local staff assistance funds to implement watershed project activities are all provided at the state level. Local land conservation committees are responsible for the administration and implementation of individual priority watersheds.

Key elements of the nonpoint-source program are as follows:

1. The program is implemented through watershed projects. Each watershed is a hydrologic unit.

2. A priority watershed project is guided by a plan. The WDNR and the DATCP and local units of government cooperatively prepare the plan with input from a local citizens' advisory committee. Project staff evaluate the conditions of surface water and ground water, and they inventory the types of land use and nonpoint sources of pollution throughout the watershed.

3. Nonpoint sources are controlled by measures or engineered structures called best-management practices (BMP's). The plan guides use of these practices in an effort to improve water quality.

4. Upon approval by State and local authorities, local units of government implement the plan. Water-quality improvement is achieved through voluntary implementation of nonpoint-source controls, BMP's, and the adoption of ordinances. Landowners, land renters, counties, cities, villages, towns, metropolitan sewage districts, sanitary districts, lake districts, and regional planning commissions are eligible to participate.

5. The county land conservation departments contact eligible landowners to determine interest in voluntarily implementing the BMP's identified in the plan. State level costshare assistance is available to help offset the cost of implementing these practices. Generally, priority watershed projects are authorized a 3-year period for signing cost-share agreements. All BMP's must be implemented within 5 years of the date of the cost-share agreement.

6. Informational and educational activities are conducted to raise public awareness of the program and to encourage participation.

7. The WDNR and the DATCP review the progress of the counties and other implementing units of government, and they provide assistance throughout the life of the project.

The NPS Program requires management actions, which are carried out through the use of BMP's, to control sources of nonpoint pollution in priority watersheds. To achieve these management actions, eligibility criteria and management categories are established in nonpoint-source control plans. Eligibility criteria determine which pollutant sources will receive funding, according to their severity. These criteria are, typically, based on (1) the biological and recreational stream classification and the effects of nonpoint sources on water quality, (2) pollution-load reductions that are needed to achieve water-quality conditions that support biological and recreational uses, and (3) watershedwide pollutant-load reductions needed to achieve downstream water-quality objectives in the priority watershed. 
Management categories define the priorities for addressing nonpoint sources of pollutants. Generally, these management categories include the following requirements:

1. Management Category I: Nonpoint sources in this category are eligible for funding and (or) technical assistance under the Nonpoint

Source Program. The sources in this category contribute a significant amount of the pollutants affecting surface- and (or) ground-water quality. Control of all pollution sources in this category is required as part of any cost-share agreement.

2. Management Category II: Nonpoint sources in this category also are eligible for funding and (or) technical assistance under the Nonpoint Source Program. Sources in this category together contribute less of the pollutant load than those included in Management Category I. Inclusion of sources in this category on costshare agreements is optional, although the success of the priority watershed project may depend on their control.

3. Management Category III: Nonpoint sources in this category are not eligible for funding or technical assistance under the Nonpoint Source Program. Sources in this category do not contribute a significant amount of the pollutants affecting surface- and (or) groundwater quality. 